DARIO GAMBONI

UNIVERSITÉ DE GENÈVE

\title{
The Underground \\ and the Virgin of Guadalupe: \\ Contexts for the Virgen del Metro, Mexico City 1997-2007
}

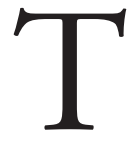

HE "Virgin OF The Underground" is the most important unofficial "apparition" of the Virgin of Guadalupe in a series that culminated at the end of the twentieth century. Its specific location and the circumstances of its discovery and reception make it also particularly rich in meanings. After recounting the main facts known about the phenomenon, this article will attempt to shed light upon it and to tackle its heuristic potential by setting it within several contexts: the anthropological one of accidental and autopoietic images; the religious and historical one of the cult of the Virgin of Guadalupe; the art-historical one of the suggestive use of coloured stone in architecture; and the sociopolitical one represented by Mexico City and its mass transpor-

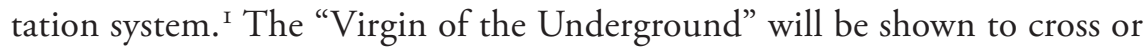
displace traditional lines separating the profane from the sacred, the modern from the archaic, the "elitist" from the popular, the "high" from the "low"-

I. This study has benefited from discussions with numerous friends and colleagues including Luisa Elena Alcalá, Francis Alÿs, Clara Bargellini, Jon Calame, Gustavo Curiel, Jaime Cuadriello, Mariana Castillo Deball, Luciano Migliaccio, Patricia Díaz Cayeros, Rita Eder, Pablo Escalante Gonzalbo, Cuauhtémoc Medina, Georges Roque, Alessandra Russo, Jean Wirth, and Gerhard Wolf. I owe a special gratitude to Peter Krieger, who enabled me to spend the beginning of 2007 in Mexico City as a guest researcher at the Instituto de Investigaciones Estéticas of the Universidad Nacional Autónoma de México and has encouraged and welcomed a written outcome of my interest in this topic. The date 2007 in the subtitle corresponds to my latest examination of the Virgen del Metro shrine. 


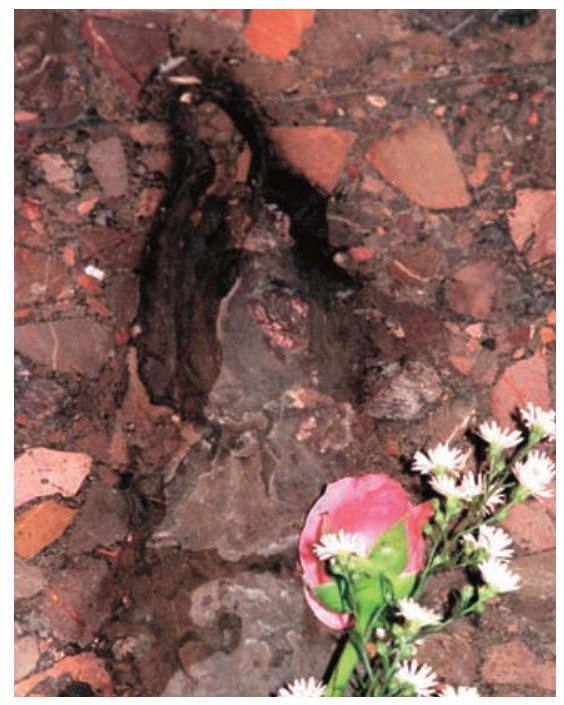

I. The image on the floor, 3 June I997, El Universal Online, photo gallery, Apariciones de la Virgen de Guadalupe, 4 February 2003.

as the very name Virgen del Metro promises and as its echoes in contemporary art will further demonstrate.

\section{From a leak to a shrine}

On I June 1997, several users of the Mexico City underground railway systemthe Sistema de Transporte Colectivo [sTC] Metro, familiarly and henceforth "Metro" - saw the image of the Virgin of Guadalupe in a water leak on the floor of a corridor in the Hidalgo station (fig. I). ${ }^{2}$ At least three persons claimed to have made the discovery: a street vendor, a twenty-year old user of the Metro, and an employee of its maintenance department. ${ }^{3}$ In the first newspaper arti-

2. See Arturo Cruz Bárcenas and Salvador Guerrero Chiprés, "Curiosidad y fervor en el Metro,” La Jornada, 5 June 1997 (http:/www.jornada.unam.mx/1997/06/05/obispo.html); Maite Rico, "Nuestra Señora del Metro," El País, ıo June 1997; Paz G. de Fernández Cueto, "Nuestra Señora del Metro," Reforma, I August 1997; Bertrand de la Grange, "La Vierge noire de Guadalupe est descendue dans le métro de Mexico," Le Monde, I3 August 1997, p. I.

3. De la Grange, "La Vierge noire de Guadalupe." According to this relatively late but well informed article, rumour had it that the employee was fired for having made the phenomenon known and thus contributed to the ensuing chaos. 
THE UNDERGROUND AND THE VIRGIN OF GUADALUPE I 2 I

2. Detail of the image in the shrine. Photo: Dario Gamboni, September 1997.

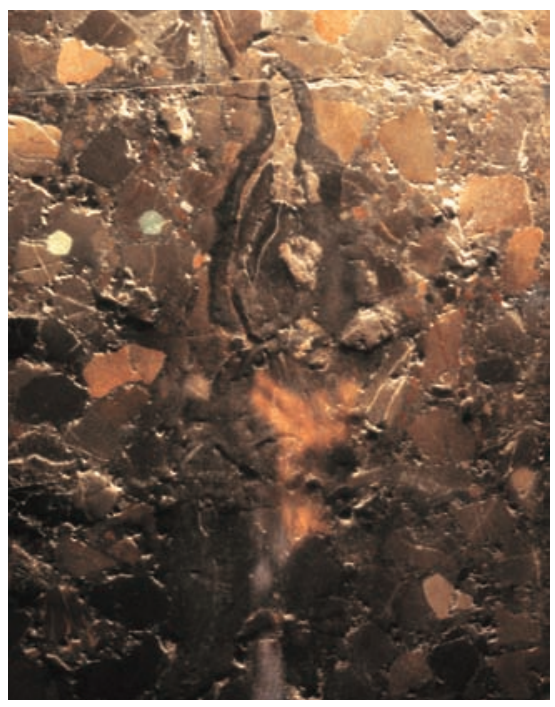

cle published on the subject, in the 5 June edition of the daily La Jornada, the young man was quoted as saying that he had noticed the leak and then seen the floor move up and down, which led him to think that it was a warning that something similar to the 1985 earthquake was about to happen in Mexico. ${ }^{4}$

The news of the "apparition" spread rapidly thanks to its reporting in all the communications media, including television, and over the following days a spontaneous pilgrimage developed, to the great annoyance of the Metro authorities who tried to prevent it by closing the corridor. As this only made matters worse, they attempted to canalise and speed up the crowd with barriers and guards. People bowed or kneeled on the floor and touched the image, depositing flowers or coins before being forced to move on. Although the water had dried up, the approximately twenty-centimetre long form remained recognisable, resembling mainly the upper part of the Virgin with the veil surrounding her head and covering her shoulders, but no facial features or bodily details visible (fig. 2).

4. "Ese primero de junio vi la fuga de agua, luego se alzó el piso pa’rriba y también pa’bajo. Pero la gente no me hace caso; les digo que algo va a pasar, aquí, en México, pero nadie me hace caso. Va a ser algo así como en el terremoto del 85" (Carlos Rafael Guevara Castillo quoted in Cruz Bárcenas and Guerrero Chiprés, "Curiosidad y fervor en el Metro"). The same Carlos Rafael Guevara is described as a candy vendor and his discovery dated to 3I May in Rico, "Nuestra Señora del Metro." 
With so much public attention focused on the event, the Church had to take position. The archbishop of Mexico City and primate of Mexico Norberto Rivera Carrera issued a statement warning against the "exploitation of popular religiosity" and what the Second Vatican Council had named "vain credulity." The press release denied the existence of "theological elements allowing one to affirm the divine presence through the lines shaped by an infiltration of water." 'Citing the miraculous apparitions of the Virgin in Mexico City in I53 I, in Lourdes in 1854, and in Fátima in 1917, it explained that their function had been to "improve upon and complete the definitive revelation of Christ." The recent event appeared to be a manifestation of curiosity prompted by the mass media rather than an expression of authentic faith, although one could rejoice in seeing pious people feeling called by God and expressing their devotion to the Virgin in the presence of "any phenomenon."

By July, the practical aim of reconciling the popular cult of the Virgen del Metro with the flow of underground users in the Hidalgo station had led the Metro authorities to an unprecedented move. They cut out a portion of the floor (approximately I $20 \times 80 \mathrm{~cm}$ ) containing the image and had it protected by a sheet of transparent plastic, framed and fixed vertically in an ad hoc construction built near one of the entrances to (and exits from) the station (fig. 3a). ${ }^{6}$ The small concrete structure, covered with blue tiles on the front and the interior, was simply called a "niche," but its arched shape including a horizontal slab underneath the image clearly evoked a shrine with its altar, and the Metro waited for the authorisation of the Church to install it. ${ }^{7}$ A rectangular protruding wall on one side supported another frame in which slogans, reproductions, statements and newspaper articles could be placed.

The shrine was inaugurated on 20 July 1997 in the presence of civil and ecclesiastical authorities and of a large crowd. ${ }^{8}$ The CEO of the Metro, Alfonso Caso Aguilar, explained that the preservation of the image had been found important

5. "No hay elementos teológicos que nos permitan afirmar la presencia divina a través de estas líneas que se han formado debido a una filtración de agua" (quoted after Cruz Bárcenas and Guerrero Chiprés, "Curiosidad y fervor en el Metro").

6. According to one source, the alms given by the pilgrims were used for the construction (Fernández Cueto, "Nuestra Señora del Metro").

7. La Jornada, 22 July 1997 (http://www.jornada.unam.mx/1997/o7/22/fotos.html).

8. Pascual Salanueva Camargo, "De la poesía a la consigna, por la Virgen del Metro," La Jornada, 30 July 1997 (http://www.jornada.unam.mx/1997/07/30/virgen.html); de la Grange, "La Vierge noire de Guadalupe." 


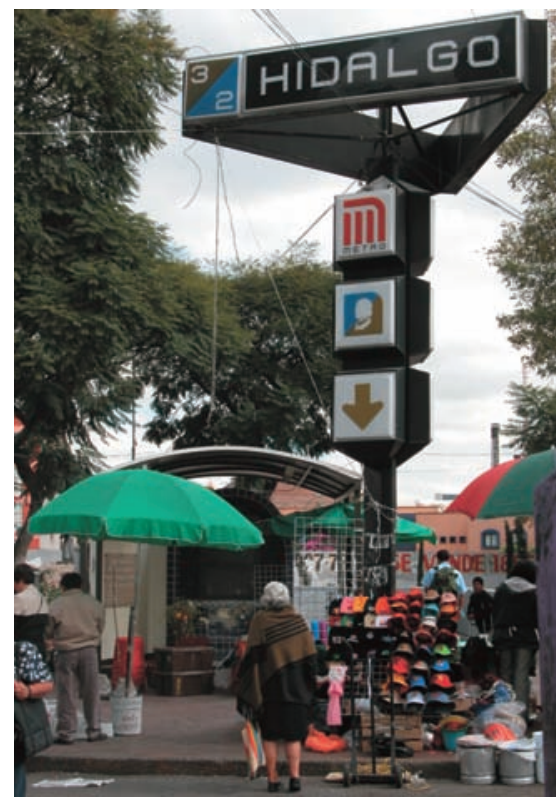

a) 3a) The shrine and the street market; b) the explanatory plaque. Photos: Dario Gamboni, November 2003.

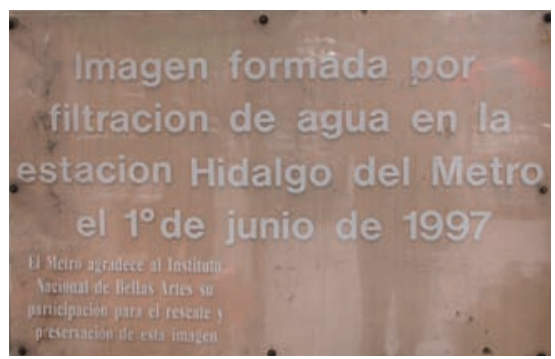

b)

by some people and that the construction represented "a tribute to our users." A plaque affixed to the interior side of the lateral wall (fig. $3 \mathrm{~b}$ ) provided an enigmatic account of the genesis, nature and status of the object that was the raison d'être of the building: "Image formed by [in] filtration of water in the Hidalgo station of the Metro on I June 1997/The Metro thanks the Instituto Nacional de Bellas Artes for its participation in the rescue and preservation of this image."9 Father Rogelio Alcántara Mendoza, who had been charged by the Archbishop with an inquiry into the phenomenon and concluded that its cause was an infiltration of water, asked the believers not to confuse "the adoration of God with the veneration of an image" and blessed the "niche." A poem was recited, songs were sung and slogans chanted - including one that mimicked those chanted at usually leftist demonstrations, "se ve, se siente, la virgen está presente" ("we see it, we feel it, the presence of the Virgin") — and a fight opposed photographers and the guadalupanos who found their presence obtrusive or their attitude disrespectful.

9. The "National Institute of Fine Arts" mentioned is an official institution devoted to the conservation and restauration of (mainly twentieth-century) art. 


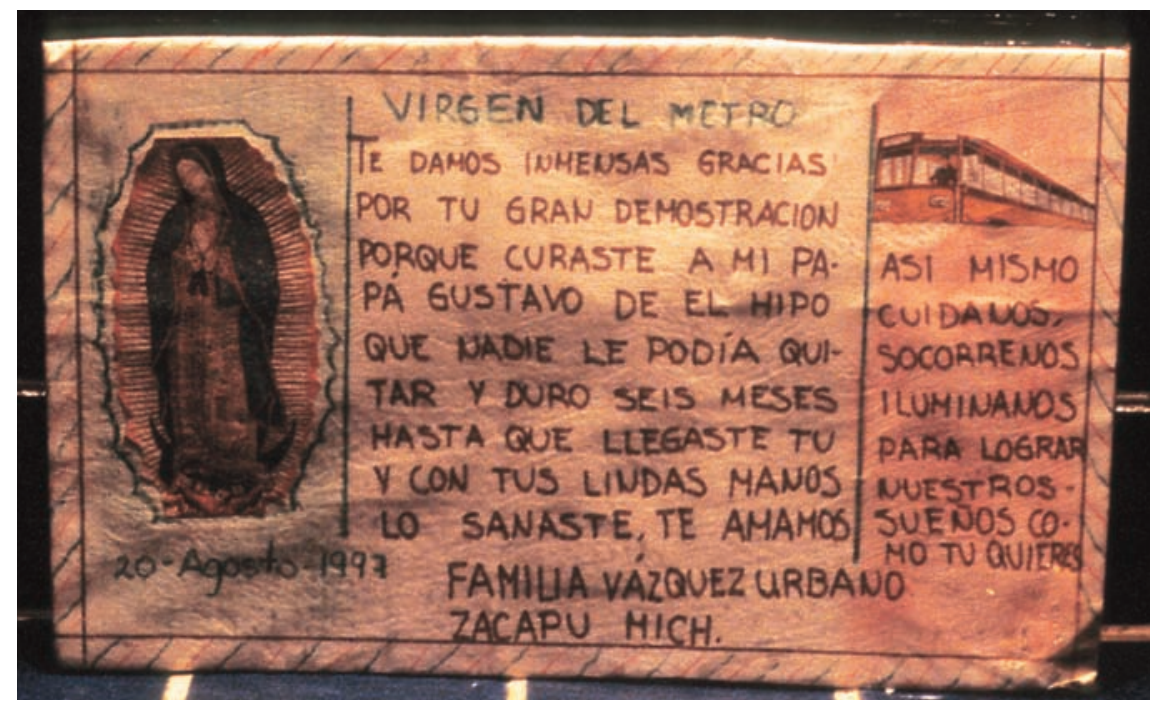

4. Exvoto placed underneath the image. Photo: Dario Gamboni, September 1997.

Presented vertically within its shrine, the Virgen del Metro remained the target of a pilgrimage and the object of an image cult. People came to contemplate the silhouette or take pictures of it and offered coins, flowers and exvotos beseeching or giving thanks for graces received (fig. 4). Over the years, a few changes were made to the construction. A long vaulted canopy supported by six metal pillars was added in front of it, probably in order to protect the worshippers from the rain and maybe to separate the niche from the street market spreading on the sidewalk (see fig. 3a). With time, the protecting plastic sheet lost its transparency so that the image became invisible, which did not prevent the faithful from recognizing and touching the exact spot where it was (fig. 5). This issue of ocular and/or tactile contact must have been a contentious one, however, since there were traces of aggressions performed with cigarettes on the lower part of the sheet and probably (given their location) directed against the growing invisibility of the image rather than against the image itself. A further transformation of the building traded a partially restored visibility of the image with an unbridgeable physical distance: the protective sheet was replaced (maybe with glass), the concrete was painted green, new orange and blue tiles were put in place and the short canopy was extended to the ground with a metal grid (fig. 6). 
THE UNDERGROUND AND THE VIRGIN OF GUADALUPE I 25

5. Woman touching the image. Photo: Dario

Gamboni, November 2002.

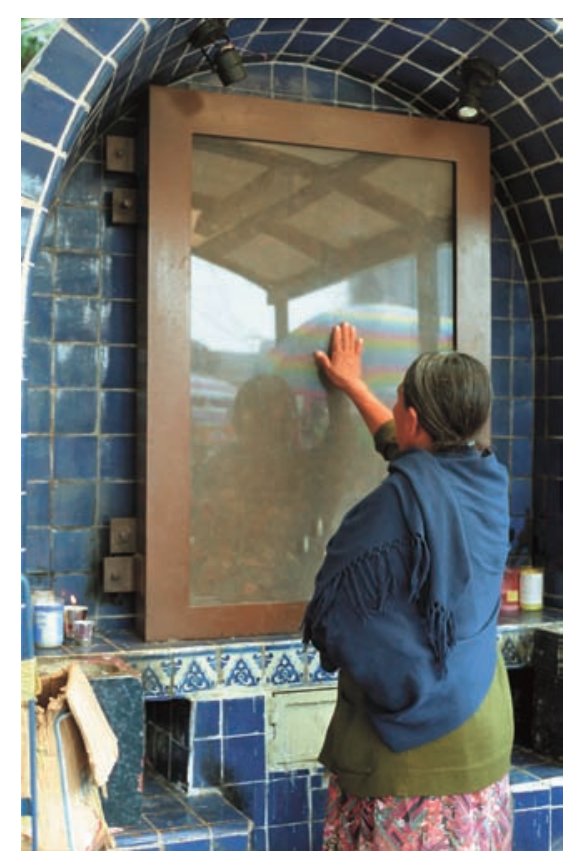

\section{Seeing the Virgin in}

The story of the Virgen del Metro is a collective case of what Richard Wollheim termed "seeing-in." " The image itself can be counted among those called "natural," "accidental" or "miraculous" depending on whether their origin is attributed-literally or metaphorically—to nature, chance or a supranatural power. ${ }^{\text {II }}$ From the point of view of modern research into visual perception, such images derive from the fact that perception consists in a selection and analysis of a portion of the information contained in the visual field, and leads to the identification of objects thanks to the confrontation of these data with those stored in associative or semantic memory. ${ }^{12}$ I have mentioned the fact that the resem-

Io. Richard Wollheim, Painting as an Art, Princeton University Press, I987, pp. 43-I00.

II. For a discussion of the terminology and typology as well as bibliographical references, see Dario Gamboni, Potential Images: Ambiguity and Indeterminacy in Modern Art, London, Reaktion, 2002, pp. 13-20.

I2. See for example Stephen M. Kosslyn and Olivier Koenig, Wet Mind: The New Cognitive Neuroscience, New York, Free Press, I995, pp. 52-I27. 


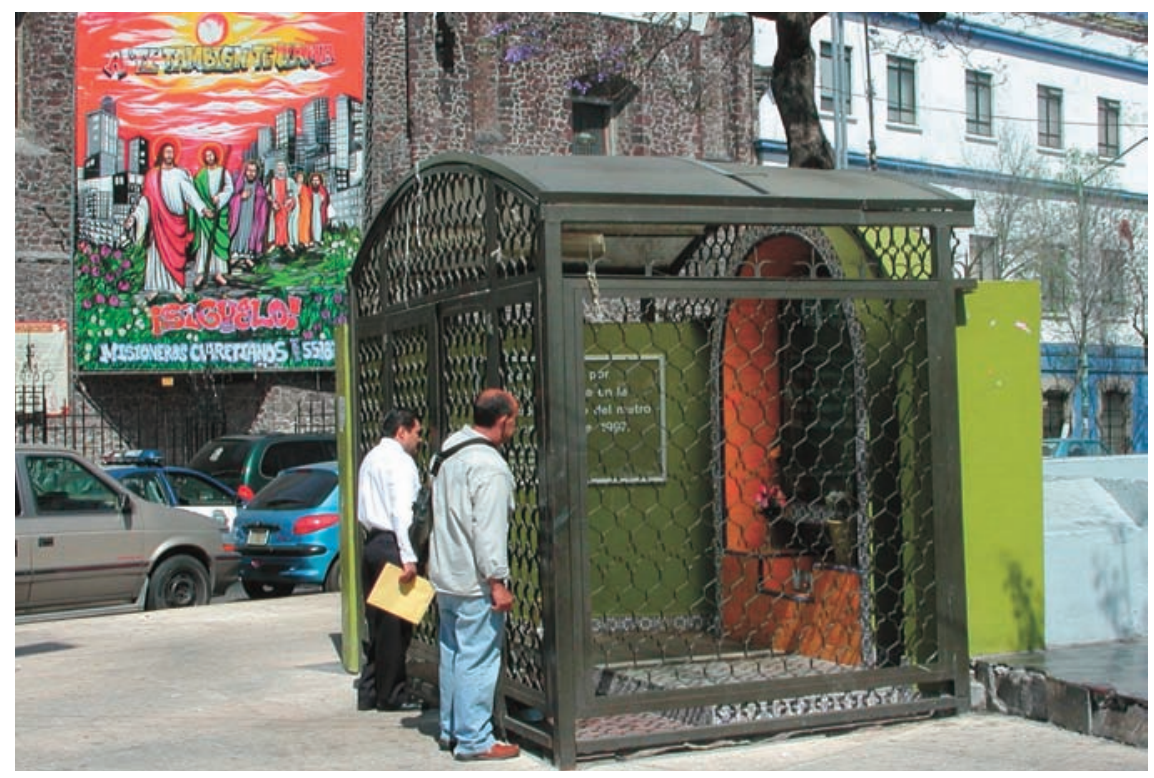

6. The shrine with grid, in front of the Templo de San Hipólito. Photo: Dario Gamboni, March 2007.

blance between the Virgin of Guadalupe and the relevant pattern in the piece of pavement appeared limited but real. I saw it for the first time in September 1997, under poor lighting conditions but when the plastic was still transparent. While acknowledging a relative similarity in the general shape of the silhouette, I also realised that I would never have noticed it in its original location myself. Somebody familiar with the Virgin of Guadalupe from infancy, however, accustomed to seeing it every day in mostly small and simplified versions, granting it extraordinary powers and cultivating a personal relationship to it, could be expected to recognise it instantly on the basis of very few elements, especially at times when its help would be needed. ${ }^{\mathrm{I} 3}$ The subjective dimension of per-

13. The simple shape of the Virgin of Guadalupe, streamlined in her flowing drapery within a cloud-enclosed mandorla sometimes compared to a uterus, clearly facilitates its ubiquitous recognition (see Jaime Cuadriello, "El obrador Trinitario o María de Guadalupe creada en idea, imagen y materia," in El divino pintor: la creación de María de Guadalupe en el taller celestial, exhib. cat., Mexico City, Museo de la Basílica de Guadalupe, 200I, pp. 6I-206, esp. pp. 74ff.). One could compare in several ways this efficient Gestalt with the minimal pattern required to see a face, which scientists have shown to be innate and explain as the evolutionary result of the 
ception that this kind of image emphasises does not, therefore, reduce it to a purely individual experience but depends on the contrary on cultural, social and historical as well as psychological factors.

The cleric entrusted with an assessment of the Virgen del Metro, father Rogelio Alcántara, distinguished between "the discovery of an image" and an apparition, explaining that the latter requires that the Virgin manifest Herself in a personal encounter, that She deliver to a living person a message consistent with the divine Revelation, and that the event be authenticated by the Church. ${ }^{14}$ The last criterion expresses the institutional will to retain control over spontaneous expressions of popular faith, and Alcántara's already quoted distinction between veneration and adoration is in line with the historical efforts of the Catholic Church to reconcile its condemnation of idolatry with its own promotion of image cult. ${ }^{15}$ However theologically founded, these oppositions do not do justice to the psychological reality of "el hallazgo de una imagen." In the absence of a knowable author or agent, the autopoietic image- to use a neutral expression - suggests a transcendent origin and prototype. ${ }^{16} \mathrm{It}$ is perceived as a message and is miraculous in and of itself, before any supranatural deed be attributed to it. The testimony of the young man interviewed by La Jornada is consistent with this semiotic and ontological structure: the movement of the floor he described expresses the dynamic character of an experience that can rightly claim to be called (in cognitive terms) an "apparition," and the reference to the 1985 earthquake underlines the portentousness of its semantic charge.

dependance of human newborns on their caretakers (see Vicki Bruce and Andy Young, In the Eye of the Beholder: The Science of Face Perception, Oxford University Press, 1998, pp. 253-254). The motherly function attributed to the Virgin gives added relevance to such a comparison.

I4. Quoted from "Revuelo por la presunta aparición de la Virgen" and "Elementos para un milagro” (2 I February 2007), Univision Online. Rogelio Alcántara published in 2004 a book entitled La Virgen del Metro devoted to these "false apparitions," which I have not been able to consult (see Alma E. Muñoz, "El fervor da origen a falsas apariciones," La Jornada, ıo December 2004, http://www.jornada.unam.mx/2004/I2/Io/o43n2soc.php).

I5. See Hans Belting, Bild und Kult: Eine Geschichte des Bildes vor dem Zeitalter der Kunst, Munich, Beck, 1990. Paz G. de Fernández Cueto made an optimistic reference to this conflictual history in her comment on the Virgen del Metro: "La Virgen fue desde un principio objeto de un culto de veneración especial llamado de dulía, que se distingue perfectamente del culto de latría o de adoración debido solamente a Dios" ("Nuestra Señora del Metro").

I6. See Gerhardt von Graevenitz et al. (ed.), Die Unvermeidlichkeit der Bilder, Tübingen, Narr, 200I, and Friedrich Weltzien (ed.), Von selbst. Autopoietische Abbildungsverfahren im I9. Jahrhundert, Berlin, Reimer, 2006. 


\section{From Tepeyac to Chicago}

The most important images offered to Christian veneration — among them the Mandylion, the Veronica, later the Holy Shroud - were called "acheiropoietic" (not made by human hands) and supposed to be of divine origin. ${ }^{17}$ The very image of the Virgen de Guadalupe, in her Mexican incarnation, derived its prestige from being recognised as a miraculous mapping of Juan Diego's visionary experience onto his tilma (woven cloak) and was therefore admitted to this select group. ${ }^{18}$ It is thus logical that one should find a reproduction of the Holy Shroud in full scale alongside that of the Virgin in the shop of the Basílica de Guadalupe (fig. 7). The denial of human agency involved in the miraculous account of the origin of the tilma image put the painters of New Spain in an ambiguous position: while the demand for replicas generated numerous commissions, their authenticity depended on an ideal transparency, so that the artists' status could only benefit from this exemplar insofar as God Himself could be shown —as in several seventeenth- and eighteenth-century pictures - to have taken the brush for its execution. ${ }^{19}$ With time, however, even the modest, emphatically hand-painted exvotos generated by the cult of the Virgin of Guadalupe came to be regarded as artworks as well as expressions of faith and were accordingly bought (or stolen), collected, and displayed.

In this long and distinguished history, the Virgen del Metro is admittedly a late and marginal episode — an epiphenomenon, maybe, worthy of a footnote.

17. See Belting, Bild und Kult, pp. 64-70, 233-52, and Herbert L. Kessler and Gerhard Wolf (eds.), The Holy Face and the Paradox of Representation. Papers from a Colloquium at the Bibliotheca Hertziana, Rome and the Villa Spelman, Florence, Bologna, Nuova Alfa Editoriale, I998.

I8. See in particular Edmundo O'Gorman, Destierro de sombras: luz en el origen de la imagen y culto de Nuestra Señora de Guadalupe del Tepeyac, Mexico, Universidad Nacional Autónoma de México, 1986; Serge Gruzinski, La guerre des images de Christophe Colomb à "Blade Runner" (1492-2019), Paris, Fayard, 1990; Stafford Poole, Our Lady of Guadalupe: The Origins and Sources of a Mexican National Symbol, Tucson, University of Arizona Press, 1995; El divino pintor; David A. Brading, Mexican Phoenix: Our Lady of Guadalupe, Image and Tradition across Five Centuries, Cambridge/New York, Cambridge University Press, 200I; and Jeanette Favrot Peterson, "Creating the Virgin of Guadalupe: The Cloth, Artist and Sources in Sixteenth-Century New Spain," The Americas, vol. 6I, no. 4, April 2005, pp. 57I-6ro.

19. See Cuadriello, "El obrador Trinitario," with reproductions on pp. I5I, I60, I63-165, I73, I77 (cat. 42-45, 49-5I), and Clara Bargellini, "Originality and Invention in the Painting of New Spain," in Donna Pierce et al., Painting a New World: Mexican Art and Life I52I-I82I, exhib. cat., Denver Art Museum, 2004, pp. 79-91, 279-8I. 
7. Shop of the Basílica de Guadalupe. Photo: Dario Gamboni, November 2002.

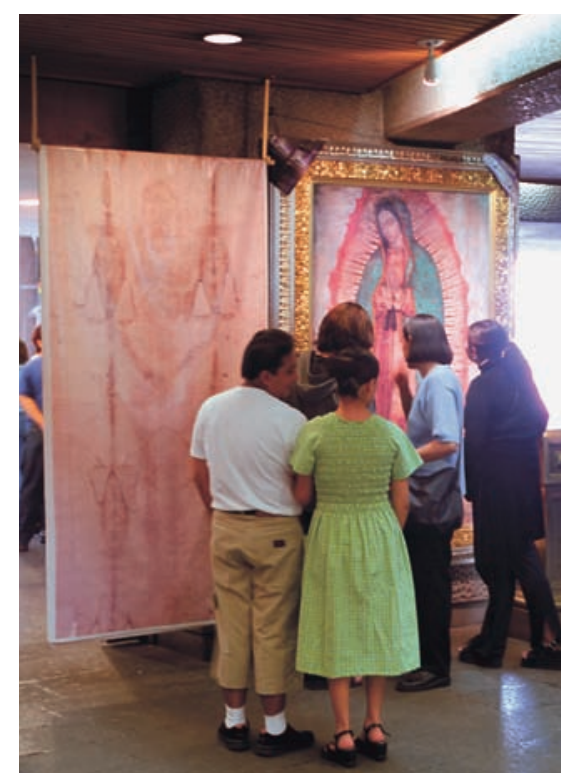

And yet, it goes back to the autopoietic character ascribed to the "original" Mexican Virgen de Guadalupe and re-enacts its tale of pious Indians fighting to convince the Church authorities of the reality of their encounter with the divine. According to Edmundo O'Gorman's fascinating account of the origin of this cult, exactly the opposite was true, and the new archbishop of Mexico City Alonso Montúfar organized in 1556 the "discovery" of the miraculous image — painted by the native artist Marcos_-on the Hill of Tepeyac, site of an ancient pilgrimage to pre-Columbian earth deities generically referred to as Tonantzin ("our revered mother"), so as to weaken the authority exerted upon the natives by the Franciscan friars who had consistently combated what they regarded as pagan idolatry. ${ }^{20}$ While inviting to consider with due caution the

20. See especially O'Gorman, Destierro de sombras; Gruzinski, La guerre des images, pp. I49I57, and Peterson, "Creating the Virgin of Guadalupe." On O'Gorman's contribution to the history of the Guadalupe, see Brading, Mexican Phoenix, pp. 326-330. Peterson defines succinctly the Mexican Guadalupe as a "fusion of an imported Mother of God with native mother goddesses" (Jeanette Favrot Peterson, "The Virgin of Guadalupe: Symbol of Conquest or Liberation?," Art Journal, vol. 5I, no. 4, I992, pp. 39-47, p. 40). She also shows that the Nahuatl verb used in the Anales de Juan Bautista for one of the first mentions of the manifestation of The Guadalupe on Tepeyac, monextitizino, was translated both as "to appear before our eyes" 
opposition between social movements arising "from above" and "from below," this explanation points to the extent to which religious practices in Colonial and post-Colonial Mexico-in particular those subsumed under the notion of popular religion-were connected with pre-Conquest notions and uses.

In the absence of alphabetical writing, images were extremely important in Nahua culture, often in the schematised and repetitive form of pictographs and ideographs. Rather than representing absent things, moreover, they were regarded as an extension of their essence and designed to make the divine world physically present. ${ }^{2 \mathrm{I}}$ The deities themselves were superhuman forces subject to constant metamorphosis, sometimes residing in rocks, plants, mountains, streams and springs; and images were connected with forms of divination involving a decipherment of the natural world. ${ }^{22}$ Such conceptions appeared at odds with the ones of the conquistadors and missionaries and were condemned as heathen and idolatrous. There were also parallels, however, between them and sacred Christian images, especially those deemed acheiropoietic, and with the notion of divine "signatures" inscribed in natural forms such as the instruments of Christ's Passion found in the passion flower. ${ }^{23}$

Since the Church itself could implicitly encourage and authorise the translation of abolished beliefs into new Christian garbs, it would not be surprising if this pre-Conquest substratum played a role in the miraculous apparitions

and "to discover" ("Creating the Virgin of Guadalupe," p. 58I), and Gruzinski mentions other cases in which sixteenth-century chroniclers define the discovery of miraculous images as "apparitions" (La guerre des images, pp. I54-I55). The ambiguity that Alcántara tried to solve was therefore present from the start and inherent in the cult of the Guadalupe. Gruzinski writes that "the I555 apparition [of the Guadalupe] amounted to the production of an ixitpla in the old sense, in the sense that the manifestation of a divine presence derived from the fabrication and presentation of the cult object" (ibidem, p. 154, and see p. 86 on the Nahuatl notion of ixitpla, used for the manifestations of gods in statues, visions, and in their personifications by priests and by human sacrificial victims).

21. Gruzinski, La guerre des images, pp. 84-88; Serge Gruzinski, Painting the Conquest: The Mexican Indians and the European Renaissance, Paris, Flammarion, 1992, pp. 13-16; see also, by the same author, El poder sin limites: cuatro respuestas indigenas a la dominación española, Mexico City, Instituto Nacional de Antropología e Historia/Instituto Francés de América Latina, I988.

22. Gruzinski, Painting the Conquest, pp. I5, I-77.

23. See for example Giacomo Bosio's treatise Della trionfante e gloriosa croce, Rome, Ciacone, I6ıo, and Ulrich Gaier, "Naturzeichen. Von Paracelsus bis Novalis," in von Graevenitz et al., Die Unvermeidlichkeit der Bilder, pp. I I7-I32. On the commonalities between the Catholic and pre-Hispanic ritual uses of images, see also Gruzinski, La guerre des images, pp. 84-8, I66-I 69, and Peterson, "Creating the Virgin of Guadalupe", pp. 582-583. 
THE UNDERGROUND AND THE VIRGIN OF GUADALUPE I 3 I

8. Anonymous, statue of El Cristo del Árbol, end of the 17 th or beginning of the 18 th century, polychrome wood, I $50 \times$ I IO $\mathrm{cm}$, Museo Nacional del Virreinato. Tepotzotlán, México. Image taken from Tepotzotlán. La vida y obra en la Nueva España, México, Sociedad de Amigos del Museo Nacional del Virreinato/Bancomer/ Joaquín Mortiz, I988, p. I94.

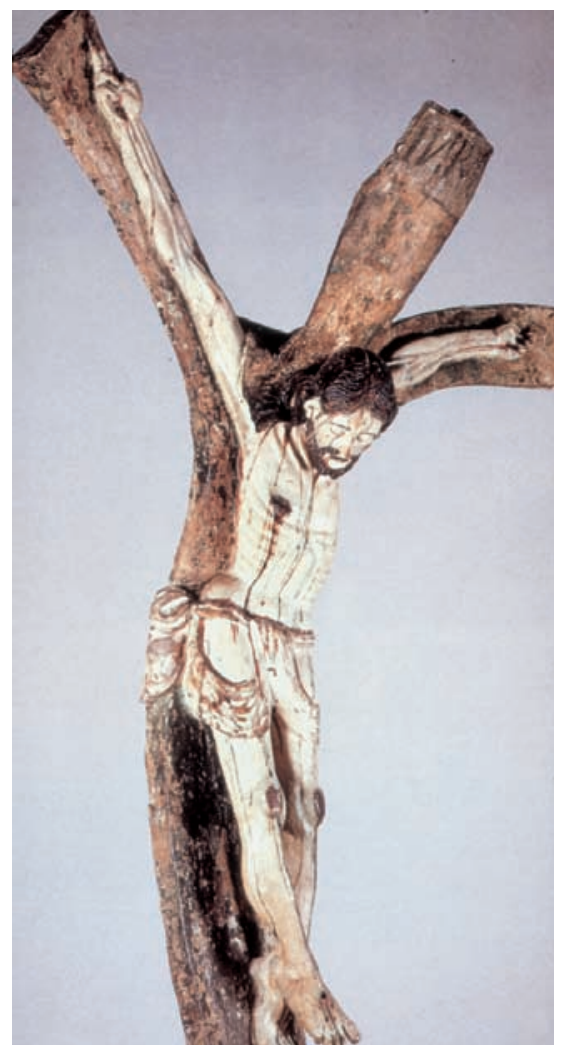

of sacred images in natural forms, especially trees, during the Early Modern period. There exist several statues of El Cristo del Árbol (fig. 8), the form of which derives from that of their support and which were said to have been "fabricated by the Sovereign Author of Nature." ${ }^{4} 4$ They could illustrate the

24. Fra Martín de Escobar's Americana Thebaida [1743-8] quoted by E.I.E.G. in the entry for El Cristo del Árbol (cat. 6) in Catálogo. Obras maestras del arte colonial. Exposición homenaje a Manuel Toussaint (I890-1990), Mexico City, Universidad Nacional Autónoma de México-Instituto de Investigaciones Estéticas, I990, p. 40; Javier Portús Pérez, entry for cat. I7I in Los Siglos de Oro en los Virreinatos de América I550-1700, exhib. cat., Museo de América, Madrid, Sociedad Estatal para la Conmemoración de los Centenarios de Felipe II y Carlos V, I999, pp. 406-407. I thank Clara Bargellini for bringing to my knowledge the Cristo del Arbol and Nuestra Señora de la Raíz. 


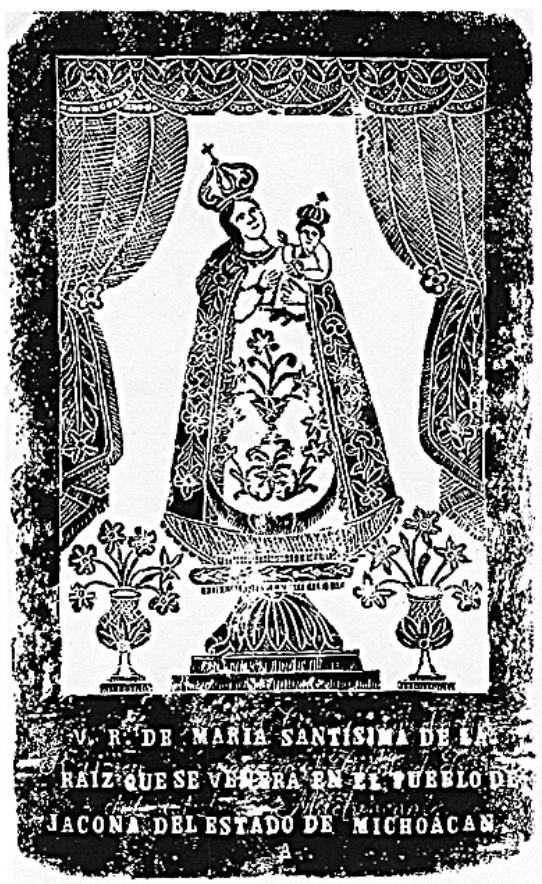

9. Anonymous, image of Our Lady of the Root, engraving. Image taken from Tapia Méndez, op. cit. (infra, n. 27), n.p.

account of the origin of sculpture given by Alberti around 1430 in his treatise De statua, but with the crucial difference that his explanation was psychological and attributed the agency to the men who, noticing a resemblance between a tree trunk or a clod of earth and "true natural figures," had come upon the idea of improving upon this accidental likeness. ${ }^{25}$ According to the legends associated with these statues, the mortals elected to encounter them were natives, or sometimes mestizos of humble origin, and the branches belonged to a Tree of Life that no axe or fire proved capable of destroying or consuming. ${ }^{26}$ Two mideighteenth-century chronicles narrate the "miraculous discovery" of Our Lady of the Root (fig. 9), a statue that "formed itself from the roots of a tree, without artifice" and was extracted from the water by Indians fishing in the lake of Chapala. ${ }^{27}$

25. Hubert Janitschek (ed.), Leone Battista Albertis kleinere kunsttheoretische Schriften (Quellenschriften für Kunstgeschichte und Kunsttechnik des Mittelalters und der Renaissance, vol. I I), Osnabrück, Zeller, I970 [1877], p. 254.

26. Catálogo. Obras maestras del arte colonial, p. 40.

27. "formóse de las rayzes de un Árbol, sin artificio" (Don José Antonio de Villaseñor y Sánchez, 
THE UNDERgROUND AND THE VIRGIN OF GUADALUPE I 33

The use of unusual materials in two-dimensional sacred images, such as mother-of-pearl in the so-called enconchados, may also hint at such (supra) natural origins; the connection of this material with notions of genesis, purity and brilliance, even the potential pun on madreperla seem particularly relevant when the Virgin is painted on the inner side of an oyster shell. ${ }^{28}$ In the nineteenth and twentieth centuries, unofficial apparitions of the Virgin of Guadalupe seem to have multiplied or to have been better recorded. She appeared as if painted on a cliff in Jalisco and on the leaves of maguey plants, an event recorded by José Guadalupe Posada in a way that emphasises the association between the Virgin, natural fecundity, and indigenous womanhood. ${ }^{29}$ Observing that the Virgin of Guadalupe had long been associated with agriculture and pulque and was sometimes called the "Mother of Maguey," Jeanette Favrot Peterson connects these apparitions with the survival of pre-Hispanic elements in popular religion. ${ }^{30}$ Used as a national symbol by the insurgent movement during the I8 Io War of Independence and by the leaders of the rebel armies during the revolutionary decade following I910, the Virgin of Guadalupe was finally appropriated by all classes of Mexican society but lost her secular institutional role after the separation of Church and State, passing into the realm of popular culture. ${ }^{31}$

The Virgen del Metro can thus boast a long ancestry in Mexico and is only the best known among many recent "apparitions" of the Virgin of Guadalupe. In its wake were reported in Mexico City discoveries made in rose petals, in the glass of a commercial refrigerator, in the bark of a tree, on a window pane, and in a building stone. ${ }^{32}$ The most frequent loci and supports of such discoveries are scars in tree trunks, which lend themselves to this specific iconic reading because of their formal resemblance to the mandorla (and at times the enclosed silhouette), and which support the perception of the Virgin as a divine power immanent in nature, enhancing it further when the trees are isolated in an

Theatro americano [...], I748, p. 80, quoted from Aureliano Tapia Méndez, Nuestra Señora de la esperanza: historia de un imagen, Monterrey, Al voleo el troquel, I997; see also Catálogo. Obras maestras del arte colonial, p. 40).

28. See Imágenes guadalupanas: Cuatro siglos, exhib. cat., Mexico City, Centro Cultural Arte Contemporáneo, 1987, pp. 92-94, I59ff.

29. See ibidem, pp. 308-310, and Peterson, "The Virgin of Guadalupe," p. 45.

30. Peterson, idem.

3I. Ibidem, p. 46. See also Brading, Mexican Phoenix, pp. 3I I-34I.

32. "Elementos para un milagro." 
urban setting. ${ }^{33}$ When noticed, these cicatrix Guadalupes become the object of collective attention and veneration, expressed in the gift of flowers, candles and alms that further feed the burgeoning pilgrimage (fig. Io). Wounds in the bark can also be connected semantically and emotionally with the Christian emphasis on suffering and penitence, while the dogma of the Immaculate Conception-one of the main theological and iconographical sources of Guadalupe-gives a paradoxical twist to its underlying theme of fecundity. Freud's analysis of humour seems fit to interpret the title Papaya virginal given by a tabloid to a story about a woman who discovered the shape of the Virgin of Guadalupe in a papaya she had just bought at the market, since the name of the fruit is also a popular designation of the vagina. ${ }^{34}$

These elements of anthropological continuity in the longue durée have not prevented the autopoietic activity of the Guadalupe from making use of the new techniques of image production, diffusion and examination, quite the contrary. Hidden images of attendants to the 153I apparitions, of Juan Diego's interpreter and of Juan Diego himself were discovered in photographic enlargements of the tilma image, specifically in the eyes of the Virgin. ${ }^{35}$ The authors of these invenciones, which took place in 1929, 195 I and 1979, were respectively the official photographer of the Basílica de Guadalupe, a draughtsman and a specialist in digital imagery; the second one, Carlos Salinas Chávez, obtained from the Church a new examination of the miraculous image by a committee of experts including ophthalmologists, who confirmed his discovery. ${ }^{36}$ Georges Roque convincingly argues that these developments are predicated upon a semiotic similarity between photographic and acheiropoietic images as indices, and he points to a seventeenth-century representation of the Tepeyac miracle that made it appear as a photograph ante litteram by suggesting the image was

33. In I6I I, the Inquisition commissioned the painter Juan de Arrué to copy the silhouette of a Virgin that had miraculously appeared on a tree trunk in Oaxaca (Gruzinski, La guerre des images, p. 203, with reference to José Rogelio Ruiz Gomar, El pintor Luis Juárez. Su vida y obra, Mexico City, Universidad Nacional Autónoma de México-Instituto de Investigaciones Estéticas, 1987, p. 59).

34. I thank Pablo Escalante Gonzalbo for bringing this story to my attention and pointing to the probable pun in the title (email to the author, 30 March 2005).

35. See Georges Roque, "Tapie au fond de l'œil, une image," Degrés, no. 69-70, Spring-Summer I992, pp. I-I3; by the same author, "Reflexiones en el ojo de la Virgen," Anales del Instituto de Investigaciones Estéticas, vol. XVIII, no. 68, 1996, pp. 9I-I I2; Brading, Mexican Phoenix, p. 343.

36. See ibidem and Juan José Benítez, El misterio de la Virgen de Guadalupe: sensacionales descubrimientos en los ojos de la Virgen mexicana, Barcelona, Planeta, 1982. 
THE UNDERGROUND AND THE VIRGIN OF GUADALUPE I 35

Io. Coyoacán, Mexico City, cicatrix Guadalupe on the side of the road. Photo: Dario

Gamboni, March 2007.

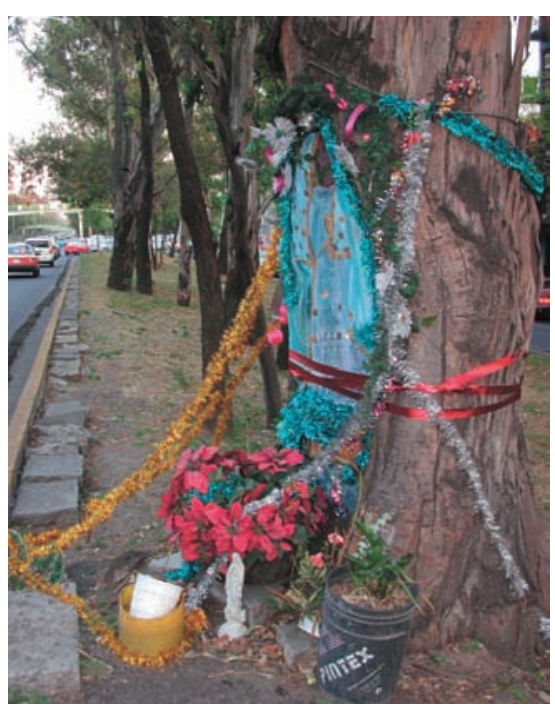

imprinted onto Juan Diego's tilma by a power analogous to the solar rays. ${ }^{37}$ Starting with prints, the cult of the Guadalupe had always been indebted to the most "modern" means of mass communication, so that, in the case of the Virgen del Metro, the Church was hardly convincing in blaming television for supporting curiosity rather than faith. It has also been shown that Marian devotion is able to take advantage of the new media and specifically the Internet, enabling communities to form beyond boundaries. ${ }^{38}$

Images of the Virgin and specifically of the Guadalupe appear also outside of Mexico. The electronic media gave a moment of worldwide fame to the sandwich that a Florida woman-purportedly ten years after discovering the Virgin staring at her while she was eating it - sold in 2004 on eBay for 28000 dollars. ${ }^{39}$ The story, which prompted a flurry of caricatures and paro-

37. Roque, "Reflexiones en el ojo de la Virgen," pp. I04-I05, with reproduction of the engraving attributed to Antonio Castro (also in Cuadriello, "El obrador Trinitario," p. I8I) and with reference to Luis Becerra Tanco, Felicidad de México en el principio y milagroso origen, que tubo el Santuario de la Virgen María Nuestra Señora de Guadalupe, 2nd ed., I675.

38. See Paolo Apolito, Internet e la Madonna: sul visionarismo religioso in Rete, Milano, Feltrinelli, 2002 (English translation The Internet and the Madonna: Religious Visionary Experience on the Web, University of Chicago Press, 2005).

39. See for example "Woman 'Blessed by the Holy Toast'," BBC News, I7 November 2004 
dies including a Van Eyck-derived Virgin Mary Eating Grilled Sandwich of Self, may have originated tongue in cheek; the sandwich was bought by an online casino for publicity purposes as "a part of pop culture that's immediately and widely recognisable." 40 But other cases appear to have involved issues of religious, social and "ethnic" collective identity in a more serious way. In December 1996, in a town named Clearwater-nomen est omen — in Florida, a giant bust of the Virgin appeared to a woman in the iridescent pattern formed by the glass panes covering an office building. The ensuing pilgrimage drew hundreds of thousands of viewers to the site, which was purchased by a religious group and further attracted crowds until a teenage boy "knocked out the Virgin's 'head' with a slingshot." $4 \mathrm{I}$

Another case of special interest in connection with the Virgen del Metro happened in Chicago, where the Guadalupe appeared in April 2005 on a concrete wall in an expressway underpass. ${ }^{42}$ Hundreds walked down to see, touch and kiss the Virgin, bringing flowers, candles and other images (fig. I I). The Illinois Department of Transportation concluded that the yellow and white stain was "likely the result of salt run-off" but intended to respect the improvised pilgrimage site "like any type of roadside memorial" until a man scrawled the words "Big LIE" with red shoe polish on the image, after which the police "painted over the stain because it had been defaced." The man, named Victor Gonzalez and aged 37, told an interviewer he had felt compelled to do it and explained: "They're not giving God the honour and all that. They're worshipping an image, and there's a big lie in there, a false miracle." 43 Rather than dis-

(http://news.bbc.co.uk/go/pr/fr/-/2/hi/americas/4019295.stm) and “'Virgin Mary Grilled Cheese” Sold for \$28,000," MSNBC.com, 23 November 2004 (http://www.msnbc.msn.com/id/65 I I I 48/). 40. Monty Kerr, spokesman for GoldenPalace.com, quoted in "Virgin Mary Grilled Cheese." 4I. I thank Jon Calame for informing me about this case. Experts attributed the image to the effect of corrosion and the teenager was condemned to ten days in jail ("High School Kid Admits Slingshot Assault on Virgin Mary Windows", 23 May 2004, http://www.roadsideamerica. $\mathrm{com} /$ news $/ 8933$ ). For another image discovered in glass - that of a thermal pane window in a private apartment-, see Robert Hanley, "Believers Crowd New Jersey Street, Searching for the Face of the Virgin Mary," The New York Times, 27 September 2000, p. A2 I.

42. See Associated Press, "Underpass Apparition. Visitors See Image of Virgin Mary in Concrete," HeraldNet, 2I April 2005 (http://www.heraldnet.com/stories/05/04/2 Iwir_virginmaryoor.cfm).

43. Victor Gonzalez's declaration to Kristyn Hartman of CBS 2 (email communication to the author by Jon Calame, 24 May 2005). See A[ssociated] P[ress], "Chicago Cops Arrest Man in Painting of Virgin Mary Stain,” USA Today, 6 May 2005 (http://www.usatoday.com/news/ 
THE UNDERGROUND AND THE VIRGIN OF GUADALUPE I 37

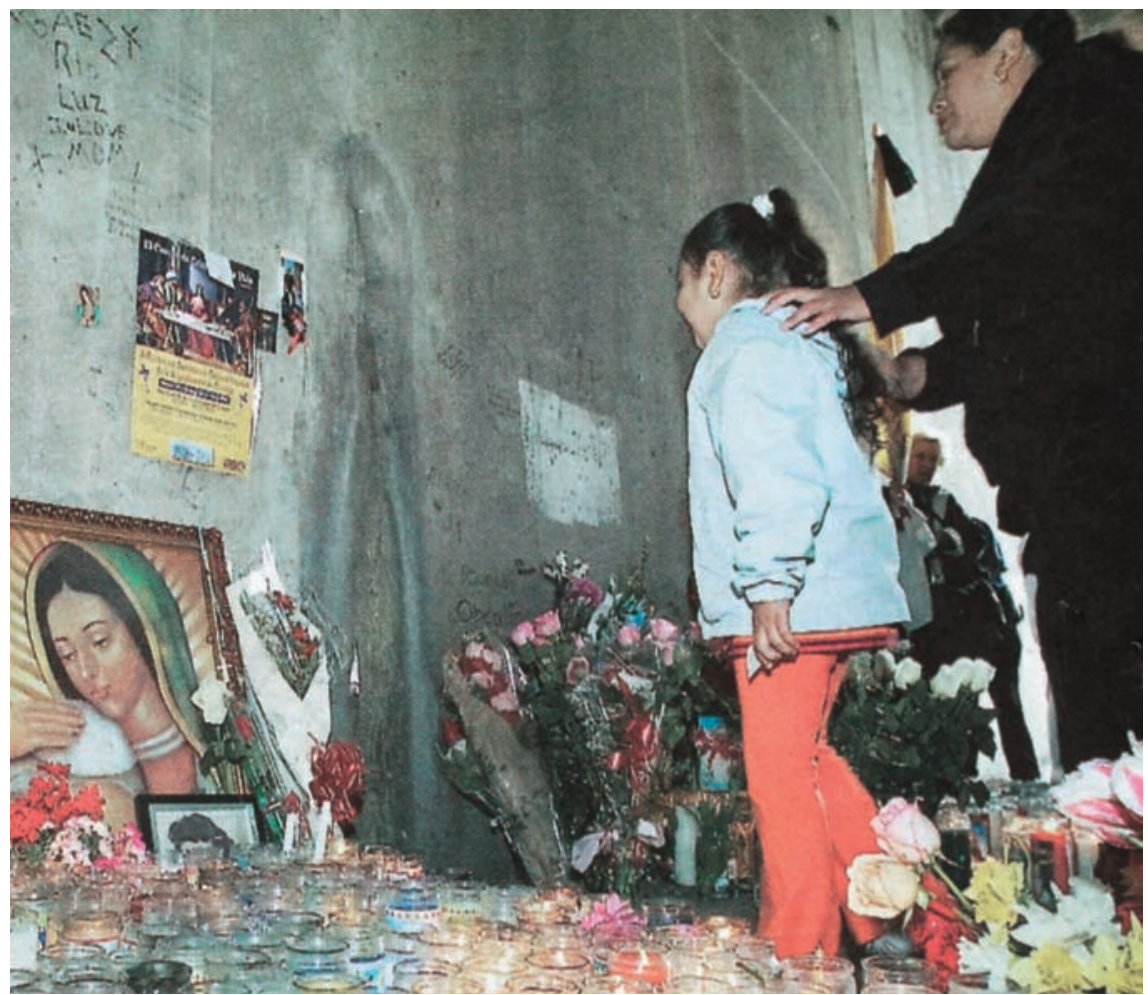

II. Woman and child looking at the image of the Virgin in the Kennedy Expressway underpass, Chicago, I 8 April 2005, image taken from 20 Minuten, 22 April 2005. Photo: EPA.

missing the resemblance or miracles altogether, the iconoclast acted therefore in the name of religion against idolatry, which puts his intervention in a long lineage including the Franciscan provincial Francisco de Bustamante's I556 sermon against Montúfar's promotion of the cult of the tilma image of Guadalupe. ${ }^{44}$

The sixteenth-century controversy had taken place in a context of heated debate about the status and legitimacy of sacred images, during the Council of Trent prompted by the Reformation and its (more or less) radical condem-

nation/2005-05-06-chixago-arrest_x.htm). Victor Gonzalez was charged with criminal damage to State supported property.

44. See O'Gorman, Destierro de sombras, pp. 8I-9I; Peterson, "Creating the Virgin of Guadalupe," pp. 584-558. 
nation of image cult. Although a more thorough inquiry would be needed, the Spanish names of the protagonists suggest that the apparitions just mentioned took place in the context of Latin American immigration in the United States, so that their controversial reception may be connected with the "frontier" situation involved. ${ }^{45}$ Other historical evidence points to a structural link between religious rivalry-which may be an element and a symbol of other competitions - and the multiplication of contested apparitions. Montúfar himself came from the Dominican monastery of Santa Cruz la Real in Granada, where the memory of the fight against aniconic Islam was still fresh. ${ }^{6}$ In I628, miraculous images of nuns and priests were discovered in cavities within an apple tree trunk near Haarlem in Holland, where Catholics were officially tolerated but had gone underground; these images were interpreted as a divine sign and promoted by means of an ad hoc print, to which the Calvinist Pieter Saenredam replied "for the love of truth" with another engraving demonstrating that the silhouettes were in fact accidental. ${ }^{47}$ One may mention as a last example the fact that the most famous (and infamous) recent apparitions of the Virgin, which have prompted the largest extant unofficial pilgrimage worldwide, started in June 198I-one year after Marshal Tito's death-in the town of Medjugorje, peopled by members of the Catholic Croatian minority of Bosnia-Herzegovina. ${ }^{4}$

45. The thermal pane window apparition took place in a "working-class, Hispanic neighborhood" of Perth Amboy, New Jersey ("Believers Crowd New Jersey Street"). For an example of iconoclastic attacks on images of the Guadalupe in a "frontier" situation, see Todd S. Purdum, "Revered Catholic Icon Becomes Mysterious Target of Vandals in Los Angeles," New York Times, 24 October 1999, p. I6.

46. See Gruzinski, La guerre des images, p. I5I; Magnus Lundberg, Unification and Conflict: The Church Politics of Alonso de Montúfar OP, Archbishop of Mexico, I554-1572, Uppsala, Swedish Institute of Mission Research (Studia Missionalia Svecana, vol. LXXXVI), 2002. The Spanish Guadalupe had been used as a symbol during the Reconquest from the twelfth century onward before being emblazoned on Hernán Cortés's banner (Peterson, "Creating the Virgin of Guadalupe," p. 577).

47. See Svetlana Alpers, The Art of Describing: Dutch Art in the Seventeenth Century, Chicago/London, University of Chicago Press, 1983, pp. 80-82; Rubens commented upon the affair by attributing what he regarded as absurdities to the proximity of Spanish troops (ibidem).

48. See M. Bax, "The Madonna of Medjugorje: Religious Rivalry and the Formation of a Devotional Movement in Yugoslavia," Anthropological Quarterly, vol. 63, 1990, no. 2, pp. 6375; Srdjan Vrcan, "The War in ex-Yugoslavia and Religion," Social Compass, vol. 43, 1994, no. 3, pp. 413-22; Élisabeth Claverie, Les guerres de la Vierge. Une anthropologie des apparitions, Paris, Gallimard, 2003. 
THE UNDERGROUND AND THE VIRGIN OF GUADALUPE I 39

As for the Virgen del Metro and the less celebrated apparitions accompanying it in Mexico during the last years of the twentieth century, commentators generally relate them to the political and economic crisis in which the country found itself and more precisely to the desperate conditions of the poor after the privatisation policy of the Salinas government. Quoting a cleaning woman who praised the Guadalupe for helping her "forget a bit the economic crisis, the delinquency, the bad government," Bertrand de la Grange concluded that "the strong religious bent of the Mexicans is being further exacerbated by the degradation of their living conditions." ${ }^{4}$ The same reasons have been put forward to explain the popularity of another, non-religious extraordinary tale, that of a monster sucking the blood of livestock and nicknamed chupacabras..$^{\circ 0}$ They may indeed have contributed to a surge of millenarism in which the Guadalupe, deriving in part from the Woman of the Apocalypsis described by St John in the Book of Revelation, had logically to be involved. ${ }^{5 I}$

\section{Suggestive surfaces}

The Chicago underpass Virgin shares two important features with the Virgen del Metro: the fact that it could also be described as a stain and its subterranean location. The stain has a paradoxical relation to the iconography of the Immaculate Conception seen in it, and it calls to mind a famous element of Renaissance art theory, the passages from Leonardo's posthumous Treatise on Painting in which he advised artists to find a stimulus to their creative power in the contemplation of stained walls, multicoloured stones and other visually indeterminate objects such as ashes, clouds or mud. ${ }^{22}$ Leonardo's approach

49. De la Grange, "La Vierge noire de Guadalupe."

50. Interview with Jaime Cuadriello, Mexico City, February 2007; see Rossana Reguillo, "La razón re-encantada: magia, neorreligión y rituales en la era del colapso," 2003, unpublished paper (http://www.hemi.nyu.edu/eng/seminar/usa/text/reguillo_paper.html).

51. Peterson, “The Virgin of Guadalupe," p. 46; Peterson, "Creating the Virgin of Guadalupe," pp. 592-594, 6ro.

52. Leonardo da Vinci, Treatise on Painting, A. Philip McMahon (ed.), 2 vols., Princeton University Press, I956, vol. I, pp. 50-51, and vol. 2, pp. 35-36. On the artistic use of stains and blots, see in particular Jean-Claude Lebensztejn, L'art de la tache. Introduction à la Nouvelle méthode d'Alexander Cozens, Paris, Limon, 1990. Georges Roque has pointed to the chronological proximity between Leonardo's advice and the Mexican Guadalupe (Roque, "Tapie au fond de l'œil, une image," pp. 4-5; Roque, "Reflexiones en el ojo de la Virgen," p. 98). 
to this phenomenon was psychological, like Alberti's, and he explained that "in confused things the mind awakes to new inventions," which emphasises the fact that the vagueness of the resemblance between the Guadalupe and the Mexico City and Chicago stains favoured rather than hindered the apparitions. In material terms, what similarity there was can probably be accounted for by the physics of fluids. The surprising fact that the Virgen del Metro remained visible once the liquid had dried would seem to derive from the composite nature of the artificial stone of the floor tiles, in which a lasting infiltration of water could modify the position and colour of unequally dense and porous elements. A crucial factor of recognition present in both stains is the slight asymmetry corresponding to the tilted head of the Virgin in the tilma image, a trait that Peterson attributes to the fact that the canvas is composed of two separate woven strips sewn up the centre and that the painter wanted to "avoid the disruptive seam and keep [the head] flawless." 53

As for the subterranean location, it obviously has wide-ranging anthropological connections with religious apparitions and cults, including those of the Virgin. This fact did not escape the earliest commentators of the Virgen del Metro who made references to the second-century Catacombs of Priscilla in Rome-a monument of the Ecclesia militans containing the oldest-known painting of Mary — and to the grotto of Lourdes. ${ }^{54}$ The site and situation of the Virgen del Metro, the specific location of its discovery in physical, institutional and cultural space on various scales has contributed greatly to the particular hold it has taken on imaginations in Mexico and beyond. Before coming back to the Metro in its entirety, the relevance of the Hidalgo station must be noted. It is named (like the nearby avenue) after Father Miguel Hidalgo, the Creole priest and instigator of independence who took up the banner of the Guadalupe in 1810 and gave her the title of "General Captain" of the insurgency. ${ }^{55}$ The connection between Hidalgo and the Guadalupe has been kept present well beyond the separation of Church and State-including in Juan O'Gorman's mural Independencia in the Chapultepec Castle in Mexico City_ ${ }^{56}$ and can be assumed to have been known by the majority of the persons involved if not by all.

53. Peterson, "Creating the Virgin of Guadalupe," p. 574.

54. Fernández Cueto, "Nuestra Señora del Metro."

55. Peterson, "The Virgin of Guadalupe," p. 45, with reference to Matt S. Meier, "María insurgente," Historia Mexicana, vol. 23, no. 3, January-March 1974, pp. 469-7I.

56. See Juan O'Gorman Ioo años-Templos, dibujos y estudios preparatorios, exhib. cat., Mexico City, Fomento Cultural Banamex, 2005, pp. 168-169. 
THE UNDERGROUND AND THE VIRGIN OF GUADALUPE I4I

Hidalgo is the interchange station between Lines 2 and 3, built during the first construction stage (1967-1972) of the Metro, and lies on the way to the northern neighbourhood of Villa de Guadalupe Hidalgo (or simply "la Villa") where the Basilica itself is located. ${ }^{57}$ Finally, the station and especially the entrance chosen for the erection of the Virgen del Metro shrine are immediate neighbours of the Templo de San Hipólito (see fig. 6), erected by the Spaniards on the site of a major 1520 battle; although dedicated to the Roman saint Hippolytus, the church has in recent decades become the centre of the popular cult of San Judas Tadeo, the "saint of desperate causes" invoked by those who have no other recourse. ${ }^{58}$

The parallels and affinities we have noticed between the Virgen del Metro and older cult images seem to lie entirely on the side of its reception. Yet a look at the history of architecture shows that the material and genetic gap between them can be partially bridged. We owe the term "acheiropoietic" to the Byzantine theory of sacred images, made for churches in which the walls were covered with slabs of multicoloured marble arranged in complex symmetrical patterns. This type of facing agreed with the Late Antique love of variegated stone, but written documents-especially the sixth-century ekphrasis (description) of Hagia Sophia - show that it was compared with painting and suggested to the churchgoers images of stars, rivers, forests, animals, and human figures. ${ }^{59}$ Although it does not appear to have been involved in the Byzantine Iconoclast controversy, its merely potential iconicity was acceptable to Islam and may have contributed to the adoption of Hagia Sophia as a model for Ottoman mosques. Before the fall of Constantinople, however, its sacking at the hands of the crusaders in 1204 had the effect of a massive transfer of precious stone to Venice, and when recommending Greek marble in his architectural treatise written in I460-I464, Filarete pointed to San Marco as well as to Hagia Sophia. ${ }^{60}$ The

57. See the remarkable entry on the Mexico City Metro in Wikipedia (http://en.wikipedia. org/wiki/Mexico_City_Metro, last consulted on I February 2009).

58. María Rivera, "San Juditas, el santo de los hijos de la crisis," La Jornada, 30 October 2000 (http:/www.jornada.unam.mx/2000/10/30/046nisoc.html). According to this article, the modern cult of San Judas Tadeo originated in Chicago and was brought back by Mexican immigrants.

59. See John Onians, "Abstraction and Imagination in Late Antiquity," Art History, vol. 3, no. I, March I980, pp. I-24; James Trilling, "The Image not Made by Hands and the Byzantine Way of Seeing," in Kessler and Wolf, The Holy Face, pp. I09-I 27.

6o. See Wladimir Dorigo, "Spolia marmorei d'oltremare a Venezia (secoli XI-XIV)," Saggi e memorie di storia dell'arte, vol. 28, 2004, pp. I-I4; Antonio Averlino Filarete, Tractat über die Baukunst, Wolfgang von Oettingen (ed.), Vienna, Graeser, I89o, p. I02. 
I 42

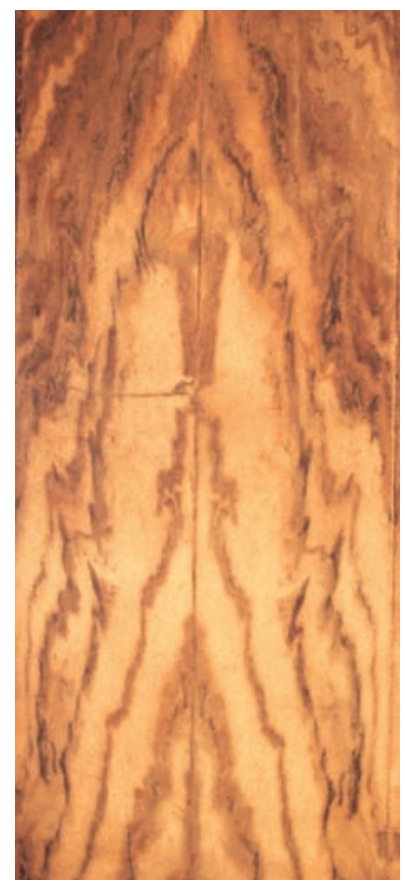

a)
DARIO GAMBONI

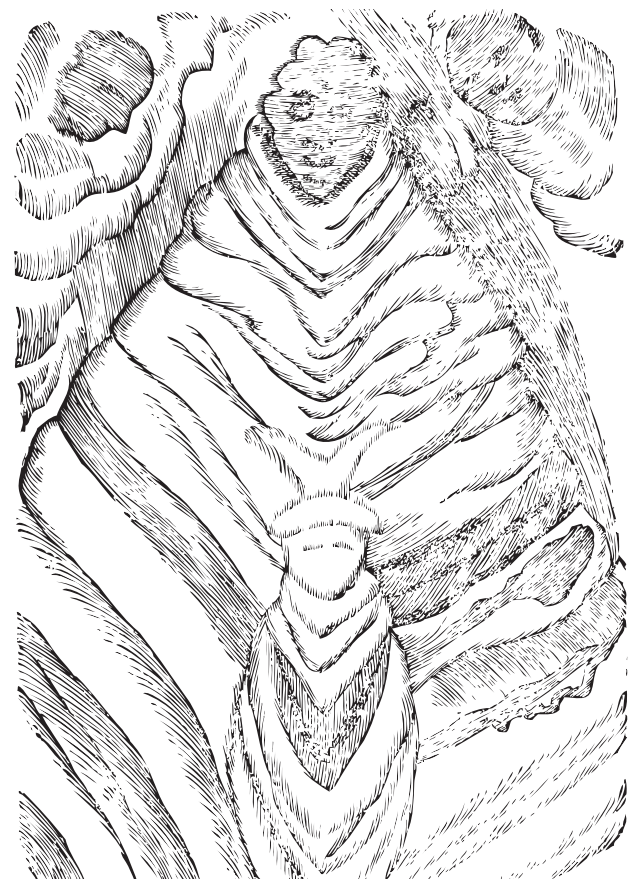

b)

I2a) Venice, wall of the San Clemente chapel in San Marco, detail of the marble facing, probably I 3 th century. Photo: Dario Gamboni, I 999; b) Anonymous, woodcut of a section of the marble facing in a Ravenna church, from Ulisse Aldrovandi, Musaeum Metallicum, Bologna, I648.

reason for his predilection can be compared to Alberti's account of the origin of sculpture and to Leonardo's advice for stimulating the imagination; however, Filarete attributed the agency behind autopoietic images to nature, writing that it often put images of clouds, plants and even animals or humans in Greek marble and that it had painted a praying hermit with a long beard and a penitent's shirt on the wall of the San Clemente chapel in San Marco (fig. I2a). The symmetry obtained by the open-book arrangement of two slabs of marble cut from a single block is conducive to the interpretation of the resulting pattern as the image of a living being, since organisms are generally symmetrical, and the seventeenthcentury representation of a marble facing in a Ravenna church (fig. I2b) gives a good idea of the way in which Filarete and later Early Modern viewers perceived such products of the "collaboration of Nature and Art." 
THE UNDERGROUND AND THE VIRGIN OF GUADALUPE I 43

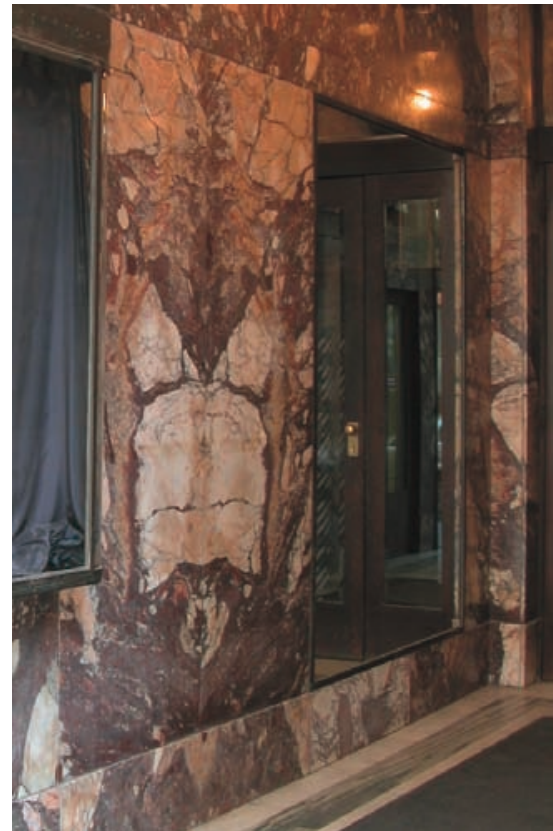

a)
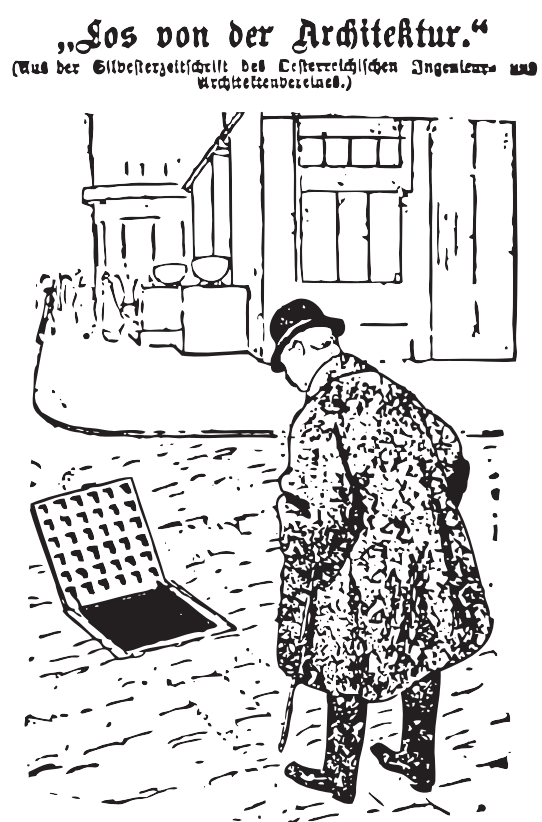

b)

I3a) Vienna, Haus am Michaelerplatz by Adolf Loos, detail of the side entrance. Photo: Dario Gamboni, 2008; b) Adolf Loos discovering the design of the façade of the Haus am Michaelerplatz on the ground, anonymous caricature in Illustriertes Wiener Extrablatt, I January I 9 I I. Image taken from Czech and Mistelbauer, Das Looshaus (infra, n. 6I), p. 73.

The semiotically intermediate nature of potential images in general and of stone facing in particular explains that it could be used not only by iconophilic cultures such as the Byzantine and the Catholic ones, in addition to explicit modes of making and seeing images, but also by aniconic or even iconoclastic cultures as a compensation for the rejection of these explicit modes. The Modern Movement is an example of the latter, and it is telling that in the first building perceived as an affront to decorum because of its radical dispensation with historicist references and ornament, the Haus am Michaelerplatz in Vienna, Adolf Loos put marble facing to highly decorative and suggestive uses - to the point of evoking the psychological test based on the interpretive perception of symmetrical blots that Hermann Rorschach was elaborating in the very same years (fig. I3a). ${ }^{6 \mathrm{I}}$ A contemporary

61. See Hermann Czech and Wolfgang Mistelbauer, Das Looshaus, Vienna, Löcker \& Wö- 


\section{44}

DARIO GAMBONI

cartoonist imagined that in his apparent departure from all architectural traditions, Loos must have been inspired by a chance image and have discovered the essential features of his façade on the ground-like the "inventors" of the Virgen del Metro-in the grid of a manhole with its cover (fig. $\mathrm{I} 3 \mathrm{~b}$ ).

It is to this second tradition, modernist, secular and aniconic, that the architecture of the Mexico City Metro primarily belongs. But in Mexico, the postrevolutionary introduction of Modernism cohabited with a propagandist use of images and with a primitivist reclaiming of the pre-Hispanic heritage. The art and architecture of Juan O'Gorman - brother of the historian Edmundois emblematic of this situation, at times schizophrenic and at times successfully syncretic. ${ }^{62}$ In the Central Library of the National Autonomous University of Mexico, which he codesigned in 1952, he not only covered the exterior walls with his celebrated stone mosaics but also let the light entering the main reading room be mediated by a sumptuous array of tecali slabs. Tecali, a travertine regarded as the Mexican onyx, had been widely employed in pre-Hispanic and in Colonial Mexico, including in thin sheets used as windowpanes by the Spaniards; on one occasion at least, an image of the Guadalupe was incised on the pane so that she appeared to be floating in an indeterminate space between the interior of the church and the sky outside of it. ${ }^{63}$ The Metro itself, which was constructed from 1967 to 1972 in its first stage, made an extensive use of stone facing and pavement (fig. I4), both with natural and with artificial stone, as on the floor of the Hidalgo station. It also included elements of iconic decoration referring to post-Independence, Colonial and especially pre-Hispanic Mexico, a period that its construction helped explore by providing opportunities for archaeological excavations and discoveries.

As an instrument and a symbol of the secular modernisation of Mexico, the Metro seems at odds with the religious tradition represented by the Guadalupe, but unexpected connections are made apparent by a contemporary

genstein, 1976; Henri Ellenberger, "The Life and Work of Hermann Rorschach," Bulletin of the Menninger Clinic, vol. I8, no. 5, September 1954, pp. 173-219.

62. See especially Ida Rodríguez Prampolini, Juan O’Gorman, arquitecto y pintor, Mexico City, Universidad Nacional Autónoma de México-Instituto de Investigaciones Estéticas, 1983; Edward R. Burian, "Modernity and Nationalism: Juan O’Gorman and Post-Revolutionary Architecture in Mexico, 1920-1960," in Jean-François LeJeune (ed.), Cruelty and Utopia: Cities and Landscapes of Latin America, New York, Princeton Architectural Press, 2005, pp. 210-23.

63. Sacristy of the church of San Dionisio in Yauhquemecan, Tlaxcala, seventeenth century, reproduced in Imágenes guadalupanas, p. 159, cat. 308. 
THE UNDERGROUND AND THE VIRGIN OF GUADALUPE I 45

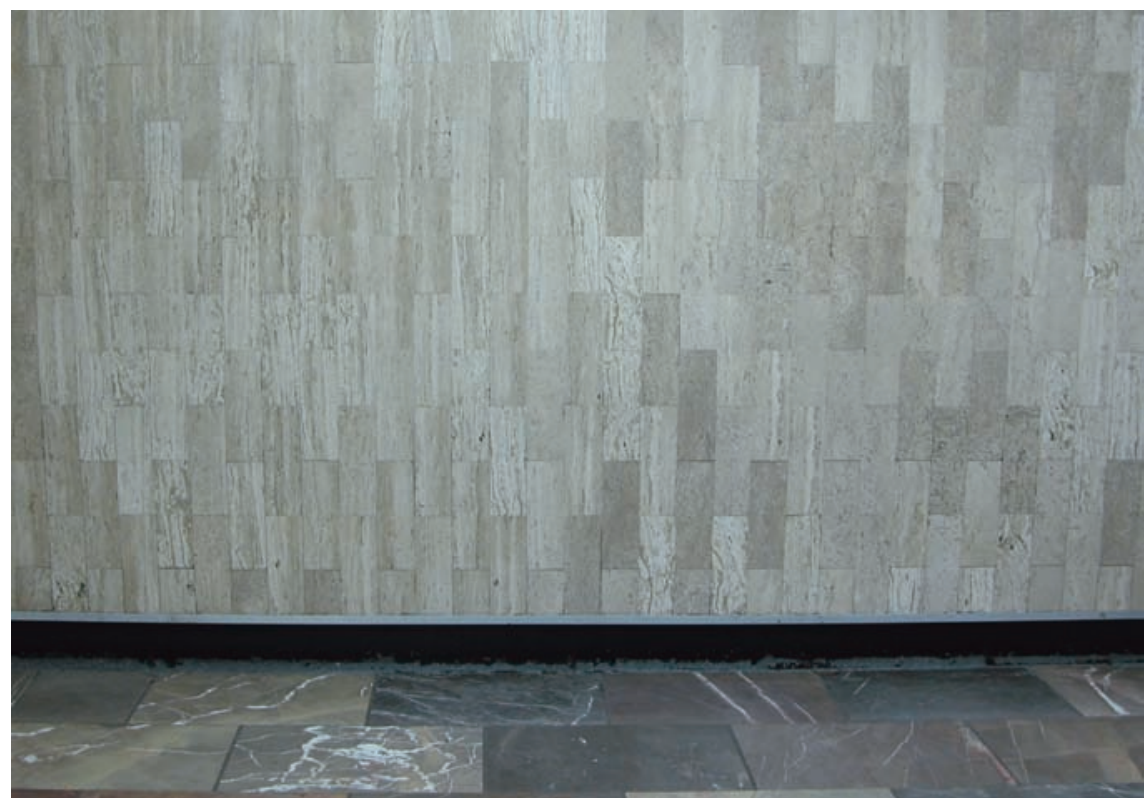

I 4. Mexico City underground, detail of the wall facing and pavement. Photo: Dario Gamboni, 2003.

move to modernise Mexican Catholicism in the wake of the Second Vatican Council, the construction in 1974-1976 of the New Basilica by the architect of the Insurgentes station, Pedro Ramírez Vázquez. ${ }^{64}$ The two buildings share a circular plan and Insurgentes possesses the most ambitious decorative program of all Metro stations, devoted to "the three cultures" and starting above the ground with a wall of neo-Mayan glyphs. In the New Basilica, the circular plan and the open interior space make it possible to see from everywhere the tilma image, hung high above the ground (fig. I5a). But one cannot contemplate it at any length from close range, even from below, because two conveyor belts placed at its foot force the spectators to move while looking at it (fig. I5b). Although these belts could be functionally compared to architectural devices such as side-aisles and deambulatories, designed since the Middle

64. See Brading, Mexican Phoenix, pp. 336-337, and Javier Pizarro and Claudia Schroeder (ed.), Ramírez Vázquez, Mexico City, Galas, 1989. Ramírez Vázquez also built the (oval) Estadio Azteca (1962-1966, with Rafael Mijares Alcérreca) for the I968 Olympics. 
DOI: http://dx.doi.org/10.22201/iie.18703062e.2009.95.2295

146

I5a) The tilma image of the Guadalupe hung in the New Basilica;
DARIO GAMBONI
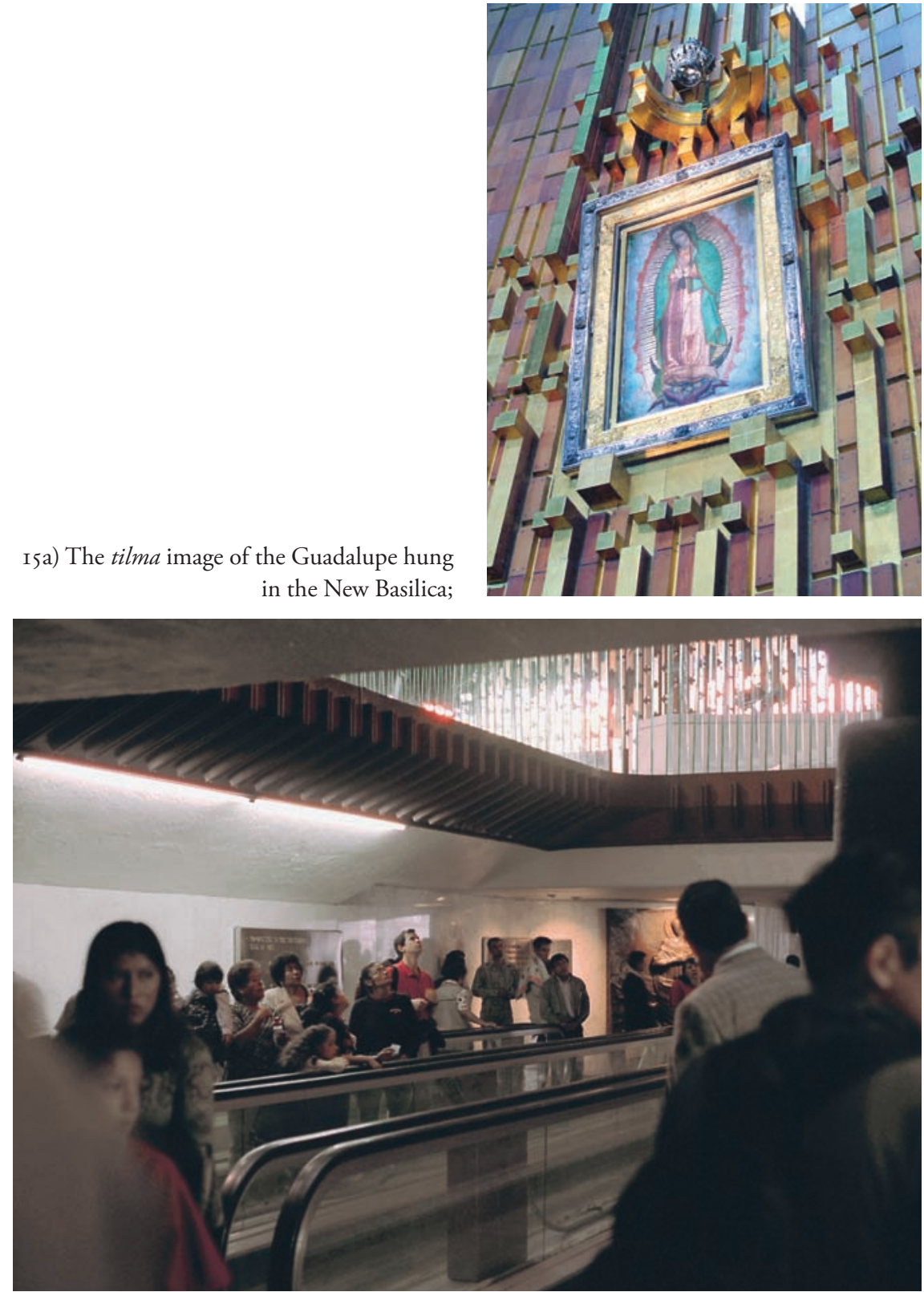

b) pilgrims and tourists looking at the tilma image from the conveyor belts. Photos: Dario Gamboni, 2002. 
THE UNDERGROUND AND THE VIRGIN OF GUADALUPE I 47

Ages to ease circulation within churches, they represent an unusually authoritarian solution more reminiscent of crowd management in airports — or in the underground. And yet Ramírez Vázquez may have been inspired with the idea by the 1964 New York World's Fair, in which another Christian and aesthetic "icon," Michelangelo's marble Pietà, was presented within the Vatican Pavilion in a darkened room that one briefly went through on a specially designed conveyor belt. ${ }^{65}$ The union of religion, art, spectacle, and mass transportation was thus taking new forms well before the I997 apparition.

\section{Our Lady of the Underground}

An unusual trait of the Virgen del Metro, which distinguishes it even from the Chicago underpass Virgin, is the fact that it was discovered on the floor. Because of the anthropological opposition between high and low, and more specifically of the triumphal meaning attributed to the gesture of treading under one's foot, floors have often been seen as problematic surfaces for the display of images. Saint Bernard protested against the depiction of angels on pavements because people could happen to spit on them, and various rules were adopted to restrict the iconography permissible on floors. ${ }^{66}$ The reverse is true in an aniconic context, and the two-dimensional images that Islam prohibits when displayed vertically are tolerated on carpets and cushions, where they cannot be venerated. ${ }^{67}$ In passing, this distinction helps to understand the ontological promotion of the Virgen del Metro as a (sacred) image when its field was delimitated from the surrounding floor and when it was raised to be offered vertically in its shrine to the public devotion. ${ }^{68}$ As for the images suggested with the help of the natural pattern of materials, they seem to have been generally acceptable. It was not living beings that one saw in the book-matched marble floor of Hagia Sophia or San Marco, however, but-interestingly, in

65. See Bill Cotter, The 1964-1965 New York World's Fair, Charleston SC, Arcadia, 2004. I thank Clara Bargellini for suggesting this connection.

66. My thanks to Jean Wirth and to Clara Bargellini for these indications.

67. Silvia Naef, Y a-t-il une "question de l'image" en Islam?, Paris, Téraèdre, 2004, pp. I8-20.

68. On the first aspect, which may easily pass unnoticed, see Meyer Schapiro, "On Some Problems in the Semiotics of Visual Art: Field and Vehicle in Image-Sign" [1969], in Selected Papers, vol. 4: Theory and Philosophy of Art: Style, Artist, and Society, New York, George Braziller, I994, pp. I-33. 
comparison with the Early Modern descriptions of vertical slabs and with the Virgen del Metro-liquid substances and a "frozen sea." ${ }^{69}$ An explicit image of the Virgin, however, would have been unthinkable, and it is telling that during the Mexican War of Independence, when the Guadalupe was used to symbolise the insurgent movement, the Royalists desecrated her image by wearing it on the sole of their shoes. ${ }^{70}$

The apparition of the Virgin of Guadalupe on the floor of the Hidalgo station of the Mexico City Metro therefore represented on many levels a turning of the tables, both completely unpredictable and profoundly logical, and one can surmise that the reversals it effected contributed to its immediate and exceptional popularity. The first line of the first newspaper article devoted to the phenomenon made this clear by simply naming the two topological opposites connected by the apparition: "Hill of Tepeyac — corridor of the Hidalgo station of the Metro."7I Lying on the ground is a helpless position of the poor and homeless, and its adoption by the Virgin was seen as an expression of humility. ${ }^{72}$ Written after the inauguration of the shrine, the article in Reforma ended by stressing the social topicality of this humility: "Our Lady of the Underground! What a modern and meaningful dedication, coming out of the very entrails of the world of labour. Our Lady of the worker, of the employee and of the unemployed; [...] Our Lady of the minimum wage [...] Our Lady of the tramp, of the thief, of the drug addict [...] Virgen del Metro: pray for us!" 73

69. See Fabio Barry, "Walking on Water: Cosmic Floors in Antiquity and the Middle Ages," The Art Bulletin, vol. 89, no. 4, December 2007, pp. 627-656.

70. Peterson, "The Virgin of Guadalupe," p. 45, with reference to Meier, "María insurgente," pp. 473-476. On iconoclastic actions directed against the Guadalupe, including during and after the Revolution, see Adrian A. Bantjes, "The War against Idols: The Meanings of Iconoclasm in Revolutionary Mexico, I910-40," in Anne L. McClanan and Jeffrey Johnson (ed.), Negating the Image: Case Studies in Iconoclasm, Williston, VT, Ashgate, 2006, pp. 4I-66.

71. "Cerro del Tepeyac-pasillo de la estación del Metro" (Bárcenas and Guerrero Chiprés, "Curiosidad y fervor en el Metro").

72. 'No importa que sea en el piso, ella es humilde y así más es su santa gloria; qué importa que sea aquí. Ella quiso que fuera aquí y ya" (Gloria Alvarado, quoted in ibidem).

73. “Nuestra Señora del Metro! Qué advocación más moderna y tan llena de contenido, al surgir de la entrańas mismas del mundo laboral. Nuestra Señora del obrero, del empleado y del desempleado; [...] Nuestra Señora del salario mínimo [...] Nuestra Señora del vago, del ladrón, del drogadicto; [...] Virgen del Metro: ¡Ruega por nosotros!” (Fernández Cueto, "Nuestra Seńora del Metro"). Paz G. de Fernández Cueto published in 1997 a book entitled La belleza de María (Mexico City, Minos), which I have not been able to consult. 
THE UNDERgROUND AND THE VIRGIN OF GUADALUPE I 49

The cheapest rail system in the world, the Mexico City Metro is not only a part of the "entrails of the world of labour" unfrequented by the rich, it is also a quintessentially public and therefore-following the separation of Church and State-secular space. Its decoration is devoid of Christian symbols and so is its system of station and service pictographs, devised initially as an indispensable way-finding tool for its numerous illiterate users. The US pioneer of signage, Lance Wyman, who had already designed the pictographs for the I968 Mexico Olympics, taking inspiration from pre-Hispanic images such as glyphs, explains that the station "icons" were chosen "to represent an important aspect of the station neighbourhood, a reference to history, an important landmark or an activity in the station area," but the absence of references to religion is none the less striking. ${ }^{74}$ The sign for the Hidalgo station (see fig. 3a), for instance, evokes the profile of Miguel Hidalgo with only the discreet line of a collar betraying his ecclesiastical status, but no hint of the Guadalupe. From this point of view, as well as from the topographical and social ones, the apparition of the Virgen del Metro announced a "return of the repressed," in accordance with Freud's comparison of the subconscious layers of the human psyche with buried archaeological strata.

This analysis seems confirmed by the embarrassed and contradictory reactions of the civil and religious authorities, equally embattled in the perennial conflict between the Mexican elites and popular culture. ${ }^{75}$ The remarkable step taken by the Metro itself to remove the piece of floor and build a shrine for it solved a practical problem that was getting out of control but also represented, as its CEO put it, "a tribute to [its] users." Accompanied by a reluctant and limited endorsement by the Church, it did not, however, signify a triumphal exit from the catacombs. The explanatory inscription (see fig. $3 b$ ) accompanying the niche speaks volumes about the resulting ambiguity: the thanks extended to the Instituto Nacional de Bellas Artes seem to locate the autopoietic image in the realm of aesthetics, but the mention of its "formation" date suggests a historical monument, and the referent or prototype of this "image" remains carefully unexpressed. The subsequent evolution of the shrine, as we have seen, further increased the distancing of the image without clarifying its status.

74. See http://www.lancewyman.com.

75. See Gruzinski, La guerre des images, 3 I 4-3 I 8, 325-327, and Bantjes, "The War against Idols." 


\section{Epilogue on a red carpet}

During his visits to the 1900 World's Fair in Paris, the US historian Henry Adams was awed by the Gallery of Machines and discovered that they embodied a power comparable to the religious one he was studying in medieval Christianity. As he later wrote in the chapter memorably entitled "The Dynamo and the Virgin" of The Education of Henry Adams, "he began to feel the forty-foot dynamos as a moral force, much as the early Christians felt the Cross." ${ }^{\prime 6} \mathrm{He}$ also reflected that the Virgin, like Venus, who had exerted the same attraction, had lost all force in (North) America, "for evidently America was ashamed of her, and she was ashamed of herself, otherwise they would not have strewn figleaves so profusely all over her." 77 As for American art, it "was as far as possible sexless," and artists "constantly complained that the power embodied in a railway train could never be embodied in art." 78

The Virgen del Metro ignores the logic of Progress and shows that one force need not replace another one; rather, they can oscillate or conceal and transfigure each other. From this point of view, the unclassifiability of the 1997 autopoietic image can be illuminating instead of obfuscating, and it is revealing to find direct or indirect echoes of it in the work of artists permanently or temporarily active in Mexico City. Francis Alÿs, who has found in the Historical Centre of the city and its "surrealism" of daily life the main site and stimulus for his work, recorded or assembled on several occasions the principal features—rather than the actual image—of the Virgen del Metro. ${ }^{79}$ Photographs taken in the I990s in the streets directs the viewer's attention to the ground and suggests an iconic and cosmic reading of it by comparing the bottle caps embedded in the asphalt to stars in the night sky (fig. I6); in 200 I, Alÿs recorded under the title Apparition of the Virgin a cicatrix Guadalupe simply adorned with flowers and seen in the same Condesa neighbourhood. ${ }^{80} \mathrm{~A}$ recent instal-

76. Henry Adams, The Education of Henry Adams: An Autobiography, Boston/Cambridge, Houghton Mifflin/Riverside Press, I96I [1918], Chapter 25, p. 380.

77. Ibidem, p. 384.

78. Ibidem, p. 385 and 388 .

79. See Francis Alÿs, Walks/Paseos, Mexico City, Museo de Arte Moderno, 1997; Francis Alÿs (ed.), The Modern Procession, New York, Public Art Fund, 2004; Francis Alÿs and Carlos Monsiváis, El Centro Histórico de la ciudad de México, Madrid, Turner, 2006.

8o. Reproduced in Francis Alÿs, Le prophète et la mouche, text by Catherine Lampert, Avignon, Collection Lambert, 2003, p. 86. I thank Francis Alÿs for the topographic information (email to the author, I4 July 2004). 
THE UNDERGROUND AND THE VIRGIN OF GUADALUPE ISI

I6. Francis Alÿs, Milky Way, I996, photograph. Reproduced with permission from the artist.

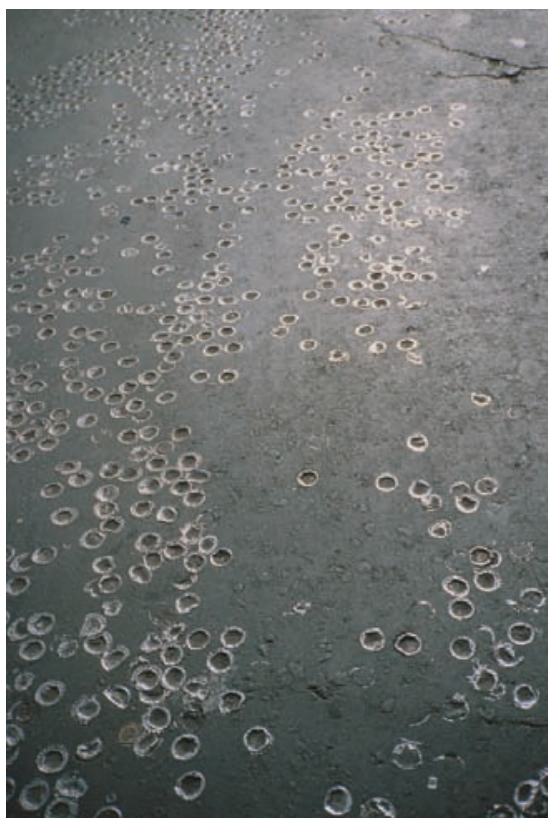

lation entitled Mendigos (2002-2004, Los Angeles County Museum of Art) projects on the ground of the gallery photographs taken from above of beggars pleading for money at the entrance of the Mexico City Metro, forcing the viewer to reflect on the hierarchy implicit in the topographical and social relationship between subject and object. Finally, the Modern Procession he organised in 2000 to accompany the temporary transfer of the Museum of Modern Art collections from Manhattan to Queens celebrated the Hispanic presence in New York and reformulated the cult of Modernism into the language of popular religion: it was meant, in the artist's own words, "to welcome MoMA's most sacred icons to the Periphery [...] for they bring us pleasure, peace, and sometimes redemption." $8 \mathrm{I}$

Invited in $200 \mathrm{I}$ to Mexico City for a one-person show at the Laboratorio Arte Alameda, a non-commercial gallery housed in the sixteenth-century convent of Santa Inés, in the immediate vicinity of the Hidalgo station and of the

8I. Brochure published by the Museum about the performance, quoted in Dario Gamboni, "Walking Icons," in Alÿs, The Modern Procession, pp. 35-43 (p. 42). 
DOI: http://dx.doi.org/10.22201/iie.18703062e.2009.95.2295

I 52

DARIO GAMBONI

I7a) Mona Hatoum, Red Carpet (Alfombra roja), I. $2 \times 150 \times 4000 \mathrm{~cm}$, taken from Mona Hatoum, exhib. cat., Mexico City, Laboratorio Arte Alameda, 2002, p. 29;
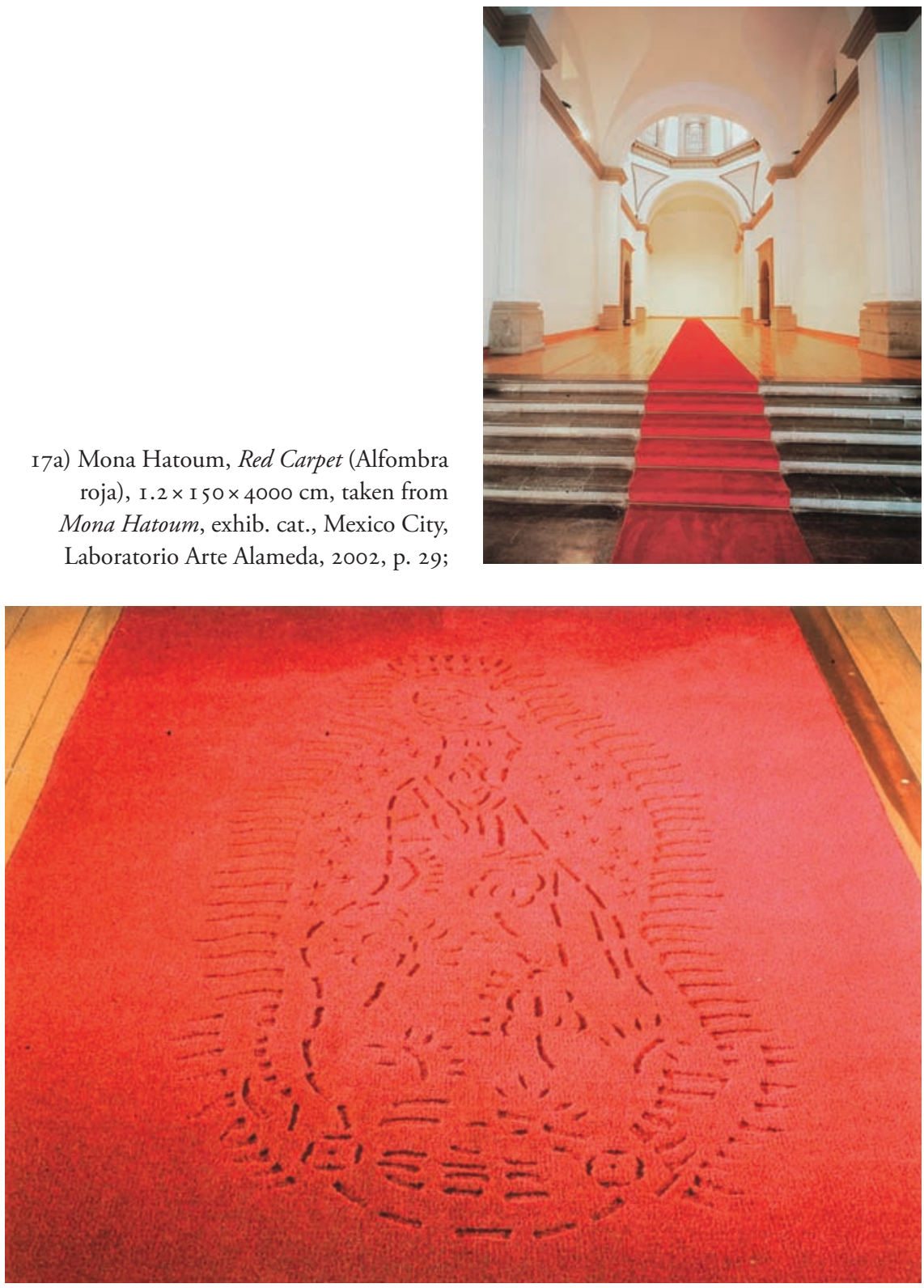

b) detail of Red Carpet with the cut image of the Guadalupe, taken from ibidem, p. 28 . 
THE UNDERGROUND AND THE VIRGIN OF GUADALUPE I 53

Alameda Central park, the Palestinian-born and London-based Mona Hatoum included a new work entitled Red Carpet. ${ }^{82}$ Adapting the traditional papel picado technique used in Mexico for decorations to celebrate holidays, she had the image of the Guadalupe cut into a long piece of woven fabric and displayed on the floor of the nave of the former convent church (figs. I7a and I $7 \mathrm{~b}$ ). Although the catalogue of the exhibition makes no reference to the Virgen del Metro, it seems more than likely that Hatoum was aware of its existence and origin, be it only because of the neighbouring shrine. Thanks to the artist's residence in Mexico and to the change of function of Santa Inés, Our Lady of the Underground received with this carpet, after many twists and turns, a sort of consecration. \$

82. Mona Hatoum, exhib. cat., Mexico City, Laboratorio Arte Alameda, 2002, pp. I2-I3, 28-29, 69-70. 